\title{
Living Hadith: The Congregational Prayers at the Great Mosque of Central Java (MAJT), Indonesia
}

\author{
Moh. Erfan Soebahar ${ }^{1}$, Abdul Ghoni $^{2}$, Kurnia Muhajarah ${ }^{3}$ \\ Universitas Islam Negeri Walisongo Semarang, Indonesia ${ }^{1,2,3}$ \\ \{erfan_soebahar@walisongo.ac.id ${ }^{1}$, abdul.ghoni@walisongo.ac.id ${ }^{2}$, kurniamuhajarah@walisongo.ac.id ${ }^{3}$ \}
}

\begin{abstract}
Congregational prayers is an obligation for male Muslims. Carrying out the prophet's orders and reviving his teachings is called living hadith. This research focuses on revealing the intention of congregational prayer for congregation at The Great Mosque of Central Java (MAJT), in living hadith perspective. MAJT as a place of worship, is also used as a religious tourism object. The dual function of MAJT is interesting to study its existence. This research is qualitative with a phenomenological approach. The research results are: first, the implementation of congregational prayers at MAJT is in accordance with hadith of Prophet Muhammad SAW. Second, the congregational prayers intention at MAJT is based on a varied understanding, without the intention of carrying out living hadith, even among the congregation performed as a complement to their religious tourism intentions.
\end{abstract}

Keywords: Living Hadith; Congregational Prayer; MAJT

\section{Introduction}

Hadith is one of the second sources of law for Muslims. Hadith is a guide that lead Muslims becomes someone religious. The existence of this hadith is one of the second important scriptures after al-Qu'an for Muslims in delivering themselves to benefit in the life of the world and later in the hereafter [1]. One of the important things contained in the hadith is the teaching of congregational prayer for men in mosques.

Congregational praying is one of the fundamental principles that can be done in measuring the level of one's faith. Prayer is a mirror in seeing the existence of someone who practices it. As a religious commandment, prayer occupies an important degree for the implementation of the religious teachings of a servant to his Lord. On the basis of the strategic value of this prayer, all Muslims try to carry out the order of prayer in congregation in accordance with the teachings and practices taught by Muhammad SAW, as the bearer of this message [2]. Prayers in congregation are also a reflection of self-discipline [3]. Guidance for the community to carry out congregational prayers is the duty of religious leaders. Exploration of the values contained in the implementation of congregational prayer is the need of the people, so that they understand the essence of this command.

The implementation of the command to pray in congregation in Indonesian is done in a different way according to each madzhab. The implementation of congregational prayer teachings as the actualization of Islamic teachings is commonly referred to as a living hadith 
[4]. The study of living hadith means a perspective in studying sacred texts [5]. In addition, living hadith is a study of live religion, practical religion, popular religion with the aim of exploring the understanding of the Muslim community in carrying out their religion [6]. Conducting a study of living hadith can be used as a theoretical, methodical, analytical basis to the dialectical movement of the scriptures towards a society [7]. This is important in order to evaluate and obtain concrete data related to religious practices carried out by the community. The conformity of the concept of the Prophet's teachings with religious practice becomes a parameter to measure the level of understanding and find a way in accordance with the original teachings.

As one of the mosques located on Semarang, the Great Mosque of Central Java is one of the important buildings. MAJT is an important icon for the people of Central Java which can be used as a source of pride in developing religious attitudes. MAJT's magnificent building is a benchmark for seeing the history of the religious development of the community.

This research attempts to answer problems related to; First, how is the practice of congregational prayers at the Great Mosque of Central Java, along with the intention of the congregation?. Second, Is there the compatibility of the practice of congregational prayer in MAJT with the hadith of the Prophet Muhammad ?. These two main problems then develop into pieces of core discussions.

Methodologically, this research is a qualitative research with a phenomenological approach. The choice of phenomenology was motivated by the intention of the researcher who tried to reveal the facts of prayer practice at MAJT as the object of study. The existence of this prayer practice is an interesting study in which it explores the understanding in the living hadith perspective.

\section{Literature Review}

The study of living hadith was widely discussed in the 2000s. Research by Saifuddin Zuhri Qudsy (2016), Living Hadith: Genealogy, Theory and Application [8] concludes a number of things, namely 1) Study of living hadith means a form of study on practice, tradition, ritual based on hadith, 2) Study of living hadith must start from the discovery of the original text, so that do not fall into analysis errors, 3) The study of living hadith requires approaches, including phenomenology, narrative studies and ethnography. Another study was conducted by Muhammad Ali (2015), who concluded that the study of al-Quran and hadith is still relevant to be developed, where textual weaknesses can be refined with practical contexts and conversely contextual practical weaknesses can be complemented by textual studies [9]. Another interesting literature review was conducted by M. Khoiril Anwar (2015), who concluded that the practice of oral tradition as a study of living hadith has been carried out by many Indonesians, especially Nahdlatul Ulama (NU) people [10].

From this literature review, it can be said that the previous studies are more on the meaning of living hadith research and its division. Locus which is the object of study is also carried out in their prespective milliu. This novelty is distinguish with the previous researches. In short, the research in this article emphasizes the practice of praying in congregation at the Great Mosque of Central Java, has never had in similar study. 


\section{Result and Discussion}

\subsection{Living Hadith}

The word living comes from English which means life. The hadith comes from Arabic which means new (al-jadid). These two words when combined have the meaning of a living hadith [11]. Living hadith is one of the research methodologies in the study of al-Qur'an and Hadith which is mostly carried out by academics. This study is the development of text studies in four ways, namely, text study (text interpretation), re-reading study of text (text reinterpretation), text reconstruction, and, the study of Muslim social phenomena related to the text of al-Qur'an and Hadith [12].

In practice, research on living hadith is divided into three types: oral, written, and practical, then developed in the study of texts towards socio-culture by making people's religious practices as the object. Each of them has a different focus in its implementation. Its application is more in an effort to analyze the teachings contained in the hadith through teaching practices in society [13]. The data obtained from the analysis of religious practices in the community. Data can be used to contextualize the teachings of the Prophet Muhammad. Then it's can be seen that the study of living hadith has an important meaning for the people.

Living hadith as a methodological offers the research point of view that looks at the phenomana of a social community. They are used as an object of study for text contextualization. In addition, this living hadith research does not intend to provide an assessment of the right and wrong of social behavior. This research only focuses on the effort to see the application of teachings to religious practice by the community. With the data obtained, it can then be used as a reference in classifying the division of society, including its affiliation in socio-religious organizations.

\subsection{Practice of Congregational Prayer at the Great Mosque of Central Java}

Great Mosque of Central Java (MAJT) is located on Jl. Gajah Raya, Sambirejo Village, Gayamsari Sub-District, Semarang City, Central Java. MAJT is a symbol of religious tourism for Muslims throughout the province of Central Java. This mosque was built on 10 hectares of land in 2001 and was completed in 2006. The building area is 7,669 $\mathrm{m} 2$, and can accommodate approximately 15,000 worshipers. Development funding comes from the Central Java Regional Budget (APBD). It was inaugurated by President Susilo Bambang Yudhoyono on 14 November, 2006. The origin of the MAJT building originated from the return of the waqf object of the Kauman Grand Mosque in Semarang, after a long process [14]. This mosque was designed in a mixed architectural style between Javanese, Islamic and Roman, which eventually became a distinctive feature of its existence.

Since its inception, this mosque has attracted tourists, but its tourist attractions are still considered minimal, so the number of visitors fluctuates [15]. Physical attractions found in this mosque include; mosque building architecture, giant umbrellas, Al-Husna Tower, convention hall, library, DAIS Radio, Mushaf al-Akbar, and Replica Bedug Purworejo. These eight things are offered by MAJT managers to attract religious tourism for the community without being limited to their area of origin.

The mosque as a place for performing congregational prayers has public facilities, among others; facilities of worship, place of ablution, bathroom / toilets, secretariat office, library, museum and other facilities that support worship [16]. Apart from these facilities, the mosque is also equipped with facilities that support Islamic knowledge and education for its visitors. 
With the existing infrastructure, religious activities are rife every day, even in certain events such as Islamic Holidays.

Some of the activities at MAJT include; Organizing obligatory prayers, organizing Islamic holidays, routine recitation, organizing Friday prayers, Islamic preaching and tabligh akbar, religious education activities (TPA, Madrasah, Community learning activities), community empowerment through collecting Zakat, Infaq, Shadaqah, and Waqf (ZISWAF) [17]. Based on the many activities at MAJT, this research focuses on the study of the congregational prayer that were established in this mosque.

The implementation of the obligatory prayer in congregation at MAJT is carried out with several series of activities which can be described as follows:

\section{a) Echoing the Call of Prayer (Adhan)}

The word adhan comes from Arabic, which is mashdar from the word al-idzan, means notification. Adhan is a call to establish obligatory prayer in 5 times a day (Fajr, Dhuhr, Asr, Maghrib and Isha). The law of echoing the call of prayer is sunnah muakkad, according to the hadith of the prophet narrated by Imam Bukhari-Muslim, from Malik bin Huwairits: "The Prophet said: When the (time) for prayer has come, let one of you say the call to prayer for you. And let the oldest among you lead you" [18].

Adhan in Islam was first performed by Bilal bin Rabbah. Bilal was chosen with the consideration that he had a loud and melodious voice. With the privilege of Bilal's voice, the Muslims at that time finally performed congregational prayers at the mosque. Adhan begins the call in performing prayers at any predetermined time.

The function of adhan is not only to signal the entry of prayer times, but also to provide benefits for driving out demons. One of the hadiths on which is relied on as narrated by anNasa'i, which reads Rasulullah SAW said: "If someone is possessed by a jinn or demon, then I will pray the call to prayer" [19]. Other functions of adhan contained include being uttered when someone is experiencing grief, a newborn and a funeral (this is still a debate among scholars). Regardless of the debate about adhan at funerals, it is known that saying the call to prayer is something valuable and beneficial to the lives of the people

When the time of obligatory prayer has arrived, the muadzin at MAJT, namely Ust. H.M. Rokhani and Ust. Hasanuddin is in charge of echoing adhan in turns. In the practice of adhan, there are several songs that are practiced at MAJT. The rhythm and the songs used do not come out of or the same as when reading the al-quran. The seven rhythms are bayati, shoba, hijaz, rost, nahawand, shika, and jiharkah [20]. Each one has its own standard and has a different rhythm effect or song chant.

In addition to the rhythm and songs above, adhan at MAJT also adopts the song of Shaykh Mishary Rasyid with a distinctive twist and its variations. These bends are either fast or slow. The adhan with each rhythm and song will have a positive impact on the listeners. The purpose of adhan with this rhythm is more about touching the hearts of the listeners. It is hoped that the listener will tremble and remember Allah as well as hasten the implementation of prayers [21].

\section{b) Iqamah}

Iqamah is a sign that the congregational prayers will soon begin. What proclaims iqamah is the muadzin which at the beginning of the entry of prayer time has echoed adhan. A muadzin has a duty to say adhan and iqamah. The time lag between adhan and iqamah usually depends 
on the agreement of the mosque or mosque management. Iqamah at MAJT is carried out 10 minutes after the call to prayer is finished.

While waiting for iqamah, muadzin at MAJT chant praises. This reading of praise contains istighfar, prayer of the prophet and advice addressed to the prayer congregation. Usually praise is recited in Arabic and Javanese and is always accompanied by prayers for the Prophet Muhammad [22]. Salawat is the core of the praise, which means that salawat to the Prophet is an order of virtue relying on the al-Qur'an, Surah al-Ahzab (33): 56 ("Verily Allah and His Angels salute for the Prophet. O you who believe. Pray for the Prophet and say greetings of respect to him ")

As for the hadith that is used as a reference in praying to the Prophet Muhammad SAW is narrated by Muslims, "From Abdullah bin Amr bin Ash RA, that he heard Rasulullah SAW say; Whoever is praying to me once, Allah will pray for him ten times. From this hadith, it is known that reading prayers on the Prophet has a positive meaning for the reader [23]. In addition, when examined more deeply, the Prophet's prayers have many virtues. This virtue is a reason for praising before iqamah. In addition, with the praise, it is used as a place to wait for the congregation to gather, before congregational prayers is carried out.

\section{c) Performing Prayers}

The object of this study is based on the implementation of the congregational prayers at the Great Mosque of Central Java. The prayers that are the object of observation are dhuhur and maghrib prayers. The choice of these two prayers was motivated by differences in the procedures for their prayers, where the dhuhur and Asr prayers are performed sirr (imam does not recite the prayer), while maghrib prayer is carried out in jahr (imam recites the prayer recitation).

As has been stated above, that the congregation praying at MAJT, not only local in Semarang people, but those who also come from outside the area with the intention of coming for religious tours. According to the data obtained, the complexity of the origin of the congregation is more found during midday prayers. Meanwhile, in the implementation of maghrib prayer, the majority of the congregation comes from around the mosque (mukim), considering that visitors outside the region have returned home or headed to other tourist locations.

Before making observations in the implementation of the congregational prayer at MAJT, the researchers first made observations to the place of ablution. The all prospective congregation prayers take ablution water which is downstairs. At that time the researcher asked them the reason for doing ablution. Some congregation states that ablution is an obligatory requirement for prayer, namely the sacredness of large and small hadats. Taking ablution water is a way to get rid of small hadats [24].

After iqamah is echoed, the congregational prayers is carried out jointly between the imam and the congregation. MAJT has the prayer faith designated by the manager in filling prayer activities in congregation. Imam were given the task of leading the congregational prayers in rotation. Apart from the 5 daily prayers, MAJT also has an imam who is in charge of leading the prayers at certain times, such as; Friday prayers, Eid al-Fitr prayers, Eid al-Adha prayers and other prayers that are incidental in nature.

Just like the implementation of prayers at other mosques, at MAJT prayers are carried out by facing the Qibla direction. The Qibla in this mosque was determined at the beginning of the construction of this mosque. This predetermined Qibla direction is agreed upon by all worshipers who follow the prayers. The essence of facing the Qibla is based on al-Quran 
Surah al-Baqarah verse 144: "Turn your face towards the Grand Mosque. And wherever you are, turn your face towards it". From this verse it means that the qibla is the Grand Mosque (Mecca).

After standing straight and facing the Qibla, proceed with the intention to offer prayers. In the researcher's observation, it is known that the prayer imam at MAJT said his intention, (although sirr however, the researcher had heard the intention he uttered). While the congregation who participate in congregational prayers intend some to say their intention and some who immediately perform takbiratul ihram. And the practice of takbiratul ihkram is done by raising both hands at the same time, some of the fingertips are equal to the shoulders and some are parallel to the ears, even above the ears.

After takbiratul ikhram, the congregation puts their hands on their stomach and some places it on their chest. After that they read al-Fatikhah and a short verse [25]. Followed by bowing, which is lowering the body into a bent position with both hands and fingers grasping the knees. During this movement, the congregation reads the recitation of the bow. After the recitation of the bow is finished, when imam reads "samiallahu liman hamidah" the congregation immediately rushes from the bow to stand back up with their hands at their sides. The movement to wake up from the bow is i'tidal. When standing after bowing, the researcher witnessed the difference in standing positions, where some of the worshipers stood with their hands at their sides, some were lilting.

After standing, then proceed with prostration, which is placing both knees, palms (open), forehead and nose to the floor. In the congregation's prostration, the researcher did not find any difference in how to do prostration. Most of the worshipers who were the object of the study performed the same prostration movement. At the time of the prostration movement, they recite a prayer while prostrating.

Getting up from prostration, after imam recites takbir, the congregation performs a sitting motion between the two prostrations. This movement is done by opening the left leg and then sitting on it. The right foot is upright, while the body is upright. Then the congregation reads a prayer between the two prostrations. After finishing sitting between these two prostrations, imam returned to takbir to prostrate again. After that, imam and congregation do the initial tasyahud sit. The movement is the same as sitting between two prostrations, but the prayer reading is different.

The last prayer movement is the final tasyahud. This movement occurred during the last rakaah. The movement begins after imam reads the takbir, followed by the left foot being inserted under the right foot. So, the pelvis sits touching the floor and the body remains straight. The palms are placed on the thighs. Fingertips parallel to knees. After finishing reading the final tasyahud prayer, proceed with saying greetings (Salam), namely Asaalamualaikum warahmatullah. At the time of reading this is continued by looking to the right and to the left. Salam is a sign of the completion of the prayer movement.

\section{d) Do'a}

After the congregational prayer is finished, imam leads do'a after the prayer. When imam led the prayer, some of the congregation left the place of prayer, and some were still intensively following the prayer read by imam. Prayers are carried out by starting with the recitation of istighfar, followed by tasbih (Subhanallah), tahmid (Alhamdulillah) and takbir (Allahu Akbar) and tahlil (La ilaha illallahu). On do'a offered by imam, the congregation assures him (saying amin). 
The phenomenon of the congregation leaving the place of prayer before imam finishes reading the prayer according to Nur Sobib (Tulung - Klaten) "I would prefer to do my own prayer, sir, because do'a together after prayer has no guidance" [26]. A different answer was expressed by Muslimin (Pedurungan - Semarang) stating "I recite do'a by myself because the one who understands my wish is myself, not the imam, right?" [27]. These two answers from the congregation indicate that the prayer is read back to their prespective and addressed to the needs of the congregation.

\subsection{Intention of Congregational Prayers}

Doing an action must have a goal to be achieved. The congregational prayers performed by the congregation at MAJT also return to the aims and objectives of the perpetrators. In relation to the background of the congregation's prayers at MAJT, there is an interesting phenomenon which according to the opinion of researchers it is important to study. As one of the pillars of Islam, prayer is an important and mandatory command. However, a person's intentions in carrying out congregational prayers contain different intentions.

Related to a person's intention in performing congregational prayers at MAJT, there are three forms of intention. The three intentions are: 1) The intention to carry out congregational prayers, 2) The intention by chance, to be at the mosque at the same time when congretional prayer held, 3) The intention of congregational prayera as a part of religious tourism. These three answers return to the capacity of each congregation's faith. Congregational prayers are carried out.

The intention to carry out congregational prayers (form 1) is mostly carried out by worshipers who live around the mosque. This was revealed by Muhaimin, who lives in the village in front of MAJT, he stated: "I try to perform congregational prayers at MAJT, because as far as I know it is my duty as a man, and I feel comfortable praying here. Besides the mosque is good, the imam is also fluent. Therefore, I choose to pray here, rather than in musholla near my house" [28]. Muhaimin's statement is a sincere impulse of faith based on the hadith that instructs men to congregate in mosques.

The intention relied on because of chance (form 2) is an orientation to pray in congregation of immigrants from outside the Semarang area. This was revealed by Budiono and Nur Shobib who unanimously stated that "the congregational prayers I did because I happened to be here (MAJT), so it would be a shame if not all the congregation" [29]. Budiono and Nur Shobib's answers to the intention of praying in congregation that they did are more on the orientation of time that is inherent in their lives.

The intention of congregational prayera as a part of religious tourism (form 3) was expressed by Muslimin (Pedurungan-Semarang) who stated that "I attended congregational prayers at MAJT because I wanted to get entertainment and inner peace. I do this every time I have a lot of thoughts, sir. I don't know why it has to be in this mosque? However, during Ramadan I try to participate in tarawih at the MAJT mosque" [30]. Muslimin statements make congregational prayer a form of religious tourism for inner peace.

From the exposure to the data above, it can be seen that the intention of following congregational prayer at MAJT is returned to a different level of faith and purposes. Each congregation has a variety of intentions that cannot be blamed. The choice of congregational prayer at this mosque is an expression of religious attitudes that arise because of the varied understanding of religious teachings and religious experiences.

On the basis of this different understanding phenomenon, the MAJT manager conducted various studies in increasing the people's understanding of prayer and other religious 
teachings. Religious education devices and facilities are directed at fulfilling these efforts. Activities at MAJT are also directed towards fulfilling the above objectives. Several studies conducted by MAJT management, among others; Teaching al-Qur'an, Majlis Taklim, Kajian Ahad Pagi, Islamic studies of Hadith, Tafsir, Tasawuf, Tilawatul Qur'an, religious broadcasts on DAIS Radio, Mosque Youth Activities. These show that MAJT strives to provide service in increasing the capacity of the congregation in every activity it carries out.

\subsection{Analysis of Living Hadith in Congregation Prayers at MAJT}

After presenting the data about the implementation of congregational prayer and the intentions of the congregation, the researcher analyzed it with descriptive analysis. The practice of congregational prayer at MAJT from beginning to end has reflected Allah's command which was manifested in the Prophet's hadith regarding the command to pray in congregation in mosques. Hadith that reveals orders to perform congregational prayers (pray you as you see me in praying). The series of congregational prayer activities carried out by imam and congregations at MAJT by performing takbiratul ikhram to greetings is a form of carrying out His commands. This study is not to justify or blame the series of congregational prayer movements at MAJT, but the data prove that the implementation of congregational prayers is in accordance with the hadith of the Prophet Muhammad SAW.

The appropriateness of the Prophet's hadith as applied in MAJT is a symbol of the life of the Prophet's teachings in the present era. The teachings of the Prophet have been reflected in the practice of congregational prayers. Indeed, the congregation did not understand that what he was doing was living hadith. However, the practice of the prayers he performs is part of it. The difference in the method of takbir, sedekap and the reading of the congregational prayers at MAJT is the influence of the reflection of different studies. This cannot be blamed, because everything returns to the realm of the ijtihad of the scholars he follows (madzhab).

Ijtihad in the implementation of the congregational prayers also has implications for the intention of the congregation. Each has the freedom to make a choice of intentions. Regarding the intention of the congregational prayers at MAJT, which is divided into three forms, according to the researchers, it is a fact that can be justified. This phenomenon cannot be ignored. Instead, it must be used as homework for the administrators and managers of MAJT to improve services for organizing congregational prayers.

That is, it would be better if the orientation of the congregation in carrying out the congretional prayers is returned to the effort to fulfill the intention of praying in congregation. Form 1 intention (implementation of congregational obligations) is a goal that needs to be cultivated in this mosque. The congregation must return to the intention of the command and virtue of the congregational prayers in accordance with the hadith narrated by Uthman bin Affan, the Prophet Muhammad said:

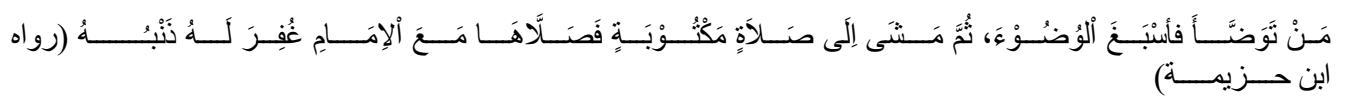

"Whoever does ablution and completes his ablution, then goes to the obligatory prayer and then performs the prayer with the imam, then his sins are forgiven" (H.R. Ibn Khuzaimah) Pieces of matan hadith ma'a al-imam, is an order to perform congregation prayers. The congregation at MAJT practiced the understanding of this hadith. The implementation of congregational prayer also requires straight intentions and is rooted in true teachings. This conception is important to be socialized massively to all congregations in straightening their 
prayer intentions. In the Prophet's hadith, it is illustrated that the virtue of praying in congregation is embodied in the Prophet's hadith narrated by Ibn Umar, the Prophet Muhammad SAW said:

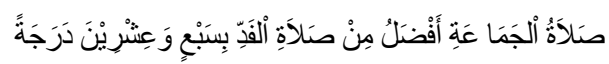

"Prayer in congregation is more important than praying alone twenty-seven degrees" (H.R. al-Bukhari, Muslim, Malik, al-Turmudzi)

The virtue of congregational prayer that is returned to the hadith is a spiritual benefit. Whereas in congregational prayer there are also socio-religious virtues [31]. According to alQathani, congregational prayer has benefits, among others; form of obedience, keep away from hypocritical nature, forgive sins, foster brotherhood. In line with this thought, asShiddiqie (2001) revealed that congregational prayers have strategic benefits for the good of religion, the good of the world, fostering brotherhood and increasing the unity and integrity of the people [32].

Thus, the command to congregational prayer has strategic value in spiritual and social improvement. This is important to be implemented by all Muslims. Cooperation and synergy between all components of the ummah (religious leaders) and the community are a main condition that cannot be abandoned. The same perception and orientation towards the wisdom of congregational prayer is important to be socialized for the sake of upholding the teachings of Islam.

\section{Conclusion}

In practice, the implementation of congregational prayers at the Great Mosque of Central Java is in accordance with hadith of the Prophet Muhammad. The prayer movement of faith and its congregation is a symbol of living hadith. The difference in movements in the prayers performed by the congregation at MAJT is a difference in the meaning of the text, not on the substance of the congregational prayer teachings. The prayer intention of the congregation at MAJT is divided into three forms, namely; 1) The Intention for carrying out congregational prayer orders, 2) The Intention by chance to be at the mosque, 3) The intention for religious tours in congregational prayer practices. The research findings above are an attempt to capture the phenomenon of religious diversity, but only focus on male congregations. This research has not penetrated the female congregation yet. The lack of this study is important to reveal intention for further research. Wallahu al-a 'lam.

\section{References}

[1] Masri Mansoer, Atiyatul Ulya, Nurkholish Sofwan, "Living Hadith: The Phenomena of Fidyah Prayer And Fasting Traditions in Indramayu", Journal Advances in Social Science, Education and Humanities Research (ASSEHR) Vol 137, (Atlantis Press, 2018) pp. 256

[2] Imam Musbikin, Misteri Shalat Jamaah: Bagi Kesehatan Fisik dan Psikis, (Yogyakarta: Mitra Pustaka, 2007), pp. 37

[3] Pemerintah Provinsi Jawa Tengah, "Penanganan Abrasi di Rembang Akan Dibuat Permanen," 2018. https://jatengprov.go.id/beritadaerah/penanganan-abrasi-di-rembangakan-dibuat-permanen/ (accessed May 12, 2020). Djamaluddin Ancok dan Nashori F, 
Psikologi Islami, (Yogyakarta: Pustaka, 2001) pp. 40

[4] Muhammad Rafi, Living Hadis: Tradisi Sedekah Nasi Bungkus Hari Jumat oleh Komunitas Sijum Amuntai, in the Jurnal Living Hadis, Vol IV No. 1, May 2019, pp.136.

[5] D Junaedi, Living Qur'an: Sebuah Pendekatan Baru dalam Kajian Al-Qur'an, in the Jurnal al-Qur'an and Hadis Studies, Vol 6 No 2 Tahun 2016, pp.172

[6] Muhammad Ali, Kajian Naskah dan Kajian Living Qur'an dan Living Hadis, in the Jurnal al-Qur'an and Hadis Studies, Vol 4 No 3 Tahun 2015, pp. 149

[7] Wahyudin Darmalaksana dkk, Analisis Perkembangan Penelitian Living Al-Qur'an dan Hadis, in the Jurnal Perspektif, Vol 3 No.2 Desember 2019, pp. 142

[8] Saifuddin Zuhri Qudsy, Living Hadis: Genealogi, Teori dan Aplikasi, in the Jurnal Living Hadis, Vol 1 No. 1, tahun 2016, (Yogyakarta: UIN Sunan Kalijaga, 2016) pp. 177-196

[9] Muhammad Ali, Kajian..., pp. 146-167

[10] M. Khoiril Anwar, Living Hadis, in the Jurnal Al-Farabi, Vol 12 No. 1 Juni 2015, pp. 72-86

[11] Muhammad bin Shalih Al Utsmaini, Musthalahul Hadis, (Kairo: Maktabah Al-Ilm, 1994) pp. 5

[12] Nurun Najwah "Tawaran Metode dalam Studi Living Sunnah" in the, Sahiron Syamsuddin (ed), Metodologi Penelitian Living Qur'an dan Hadis, (Yogyakarta: TH Press, 2005), pp. 132-134.

[13] M. Alfatih Suryadilaga dkk, Metodologi Penelitian Hadis, (Yogyakarta: Pokja Akademik UIN Sunan Kalijaga, 2006) pp. 193

[14] Wikipedia.org

[15] Shindy Taftia Ramadhani dan Hadi Wahyono, Pariwisata Keagamaan di Masjid Agung Jawa Tengah, in the Jurnal Teknik PWK Volume 2 No.32 Tahun 2013, (Semarang: Universitas Diponegoro, 2013) pp. 491

[16] Central Java Grand Mosque Information System Document.

[17] Republic Indonesia Ministry of Religion Mosque Information System Document (Simas)

[18] Shahih al-Bukhari (II/111) and Shahih Muslim (I/465 no.674)

[19] Sunan Al Kubra, Hadith Number 10791. Regarding this hadith, al Hafidz al-Haitsami in the book Jami 'al Hadith (14/279) states that the hadith is a sahih hadith, because the narrators are also authentic.

[20] Quated from dari https://palembang.tribumnews.com/amp/201909/27/jenis -iramalagu-adzan Strengthened by interviewing Ust Hasanuddin on augst 2, 2020

[21] Interview with Ust Hasanuddin, on 2 August, 2020

[22] Praise made between the call to prayer and iqamah according to research has a positive impact on the development of children's spiritual intelligence. See Tutik, Ulfa and Mohammad Tsaqibul Fikri, "Pujian Setelah Adzan untuk Perkembangan Kecerdasan Spiritual Anak", in the Jurnal At-Tuhfah: Jurnal Studi KeIslaman Vol.9 No.1, 2020

[23] The virtue of shalawat has been exposed by many experts, among others; Assegaf (2009), he describes 11 virtues of shalawat; 1) as part of obeying Allah's commands, 2) Providing harmony with Allah SWT, 3) Receiving 10 times reward, 4) Given 10 degrees by Allah, 5) Written as having 10 goodness and removing 10 badness, 6) As an introduction to ijabah prayer, 7) getting forgiveness of sins, 8) being brought closer to the Messenger of Allah on the Day of Judgment, 9) There is fulfillment of desire, 10) Purifying oneself, 11) As a reminder to Allah. See Habib Abdullah Assegaf and Indriya 
R. Dani, Mukjizat Shalawat, (Jakarta: Qultum Media, 2009), pp. 2-14

[24] Extracted from interviews with Muhiyidin (From Pekalongan), Sukirman (From Demak) and Budiono (From Pati) on 3 September, 2020 at MAJT

[25] Spoken by Muslimin (from Pedurungan - Semarang) on September 3, 2020

[26] Interview with Nur Shobib, on 3 September, 2020

[27] Interview with Muslimin, on 3 September, 2020

[28] Interview with Muhaimin, on 3 September,2020

[29] Interview with Nur Shobib and Budiono, on 3 September 2020

[30] Interview with Muslimin, on 3 September, 2020

[31] Abu Abdillah Musnid al-Qathani, Arba'una Faidatan Min Fawa'id Sholat al-Jamaah, (trans), Ainul Harits bin Umar Arifin, (Jakarta: Darul Haq, 2000) pp. 3-8

[32] Muhammad Hasby Assiddiqie, Tata cara Shalat, (Semarang: PT. Pustaka Rizqi Putra, 2001) pp. 380-383. 